\title{
Working Capital, Firm Performance, and Firm Value: An Empirical Study in Manufacturing Industry on Indonesia Stock Exchange
}

\author{
Bambang Sudiyatno, Elen Puspitasari, Sri Sudarsi \\ University of Stikubank, Semarang, Indonesia
}

\begin{abstract}
This study investigated the effects of working capital policy on firm performance and firm value. The research was conducted by manufacturing companies listed in Indonesia Stock Exchange from 2010 to 2013. Variables used as a proxy for working capital policy are current assets to total assets and current liabilities to total assets. This study uses capital structure as a control variable. Capital structure proxies by leverage. Variables used as a proxy for the performance of the company, namely return on assets, and the value of the company is Tobin's Q. Methods of data collection use purposive sampling. The results showed that current assets to total assets have an positive, significant effect on firm performance. Current liabilities to total assets and leverage have an negative, significant effect on firm performance. Furthermore, return on asset has an negative, significant effect on the firm value.
\end{abstract}

Keywords: legal decision making, case predictions, confidence judgments, metacognitive realism

\section{Introduction}

Working capital of the company consists of two main components, namely current assets and current liabilities. Current assets are a form or manifestation of the real working capital or working capital, which is the sum total of current assets. However, the current debt is a source of working capital which is financed. Both are very important in ensuring the implementation of activities of the company, where the position of current assets shows the availability of working capital, while the position of current liabilities shows the availability of sources of financing of the working capital. Therefore, the management of current assets and current liabilities becomes a very important part for the companies; the management of current assets and current liabilities is called working capital management.

Management of current assets and current liabilities will determine the future of the company, the company's performance, and development of the company, because the management will be related to the ability of the company to run its operations. Current assets on the one hand, which include cash, accounts receivable, and inventory demonstrate the company's ability to perform activities of productivity. While the current liabilities on the other hand show the company's obligation to be met by the availability of cash,

Bambang Sudiyatno, Dr., Faculty of Economics and Business, University of Stikubank, Semarang, Indonesia.

Elen Puspitasari, Dr., Faculty of Economics and Business, University of Stikubank, Semarang, Indonesia.

Sri Sudarsi, Faculty of Economics and Business, University of Stikubank, Semarang, Indonesia.

Correspondence concerning this article should be addressed to Bambang Sudiyatno, Kendeng V Bendan Ngisor, Semarang, Indonesia. E-mail: bofysatriasmara@yahoo.com/elenmeiranto@yahoo.com. 
accounts receivable, and inventory within the company. Thus, management needs to determine the composition of current assets and current liabilities for the company liquidity to gain the trust of the community.

Lamberson (1995) stated that the management of working capital is a very important issue within a company, in which some financial managers seek to identify the concept of controlling working capital and working capital adequacy level. The adequacy of working capital will affect the activities of the company, and more broadly to the business activities. With sufficient working capital, then management can more freely creat products the market needs.

Working capital management can efficiently create economic value for the company, where the influence of the economic value is to increase the performance and value of companies. Working capital management is aimed to consider the balance between maintaining liquidity and profitability. If management is too lax to maintain liquidity, so that the company's liquidity is high, then the impact will be able to reduce profitability. Vice versa, if the management is too strict to maintain liquidity, so liquidity is low, then the impact will improve profitability. Therefore, to maintain the balance of liquidity is very important for the profitability of the company that produced the maximum.

Working capital management is very important, because it can affect the performance of the company. This requirement will also be able to influence the market value as the impact of business activities, which will be an attraction for shareholders and investors. Therefore, according to Shin and Soenen (1998), and Afza and Nazir (2007), the entry point of efficient working capital management becomes an important part of the overall strategy of the company to create shareholder value. In line with these opinions, Ganesan (2007) states that the optimization of the balance of working capital management means to minimize working capital requirements and maximize revenue, so that the efficiency of working capital management and the company's free cash flow increase, which means increasing the chances of growth and returns for our shareholders (Azhar \& Norita, 2010).

Afza and Nazir (2007) stated that the company tries to maintain an optimal working capital to maximize the value of the company. While Christopher and Kamalavalli (2009) state that the efficient working capital management makes it possible to obtain significant results and this omission can be very dangerous for any company. Eljelly (2004) states that an efficient working capital management related to the planning and supervision of current assets, and current liabilities in a way eliminates the risk of inability to meet short-term liabilities by avoiding excessive investment in these assets. While Siddiquee and Khan (2009), indicate that the inefficiency of working capital management not only reduces profitability, but eventually may also lead to a financial crisis at every company, regardless of profit orientation, size, and nature of business (Azar \& Norita, 2010). In other words, the inefficiency of working capital management will be a very broad impact on the survival of the company.

Based on the explanation of the concept of working capital management mentioned above, the researchers were motivated to do research on this issue. Therefore, the problem in this research is the relationship between working capital management, corporate performance, and the value of the company, particularly in the manufacturing companies listed in Indonesia Stock Exchange.

\section{Theory and Hypothesis}

The term working capital comes from the street vendors in the US that fill his cart with merchandise, and then sell it on the route (Brigham \& Houston, 1998). Merchandise in the cart is their working capital, because 
the merchandise is sold or played back at a profit. Thus, the working capital is the capital used for the purposes of the company's operations and generates profit and working capital turnover is relatively short, i.e. less than one year. Brigham and Houston (1998), and Koh, Ang, Brigham, and Ehrhardt (2014), state that the working capital is the firm's investment in short-term assets, namely cash, marketable securities, inventories, and accounts receivable, while, net working capital is the difference between current assets less current liabilities.

Conceptually working capital can be grouped into three, namely quantitative working capital, qualitative working capital, and functional working capital. Quantitative working capital is the sum total of current assets without seeing the quality of the current assets, and working capital is often referred to as gross working capital. Qualitative working capital represents the difference between current assets and current liability and working capital is often called net working capital. Meanwhile, the functional working capital is appropriate working capital assets within the workings of the functions generating revenue. According to this concept, working capital is capital that generates current income.

Therefore, management of working capital includes the management of current assets and current liabilities of the company. Liquid assets consist of cash, short-term securities, accounts receivable, and inventory, while current liabilities consist of accounts payable, notes payable, salaries payable, taxes payable, and accounts payable rent, etc. Working capital management is very important for the company, because it will affect the company's performance and corporate value. According to Brigham and Houston (1998), and Koh et al. (2014), working capital policy involves two fundamental questions: (1) how the amount of the current assets should be owned by the company, either in total or for each specific account, and (2) how it should be financed current assets? The management of working capital involves defining the working capital policy and the implementation of those policies in daily operations (Brigham \& Houston, 1998).

In connection with the policy of working capital, current assets as working capital, Brigham and Houston (1998), state that the policy of investment in current assets includes three alternative policies, namely, current asset investment policy loose, the investment policy of strict current assets, and current assets and investment policies are moderate. The impact of each policy will certainly bring different consequences to the company, because it is closely related to policy risks, costs, and profits.

Current asset investment policy loose will cause the amount of cash, marketable securities, accounts receivable, and inventory are large. This policy will assign credit sales loosely, causing a large amount of accounts receivable. As a result, current assets turnover is low, and the cost of investment in current assets rose with earnings reduced. This policy is to maintain the operating risk of the company, because the company gets sufficient reserves of the amount of inventory to ensure smooth operation of the company. But with the growing inventory, the cost incurred the inventory of damage to be high, and this bias reduced profits.

Current assets investment policy tight will cause the amount of cash, marketable securities, accounts receivable, and inventories are low. This policy will assign a credit sale strictly, resulting in a lower amount of accounts receivable. As a result, current assets turnover is high, the cost of investment in current assets down, and profits to rise. This policy can lead to a high risk operation, because the amount of the reduced availability of the low may cause the company's working capital deficiency, so that the smoothness of the operation can be interrupted, and may result in a delay in the delivery of product orders that could interfere with the customer's trust.

Working capital management companies in the implementation are to manage cash, marketable securities, accounts receivable, and inventory on the one hand, and on the other hand how the cash, marketable securities, 
accounts receivable, and inventory will be financed. This management is essential to maintain a balance between getting a high profit by keeping the liquidity of the company. Working capital management has an impact on the company's performance and corporate value. High profits will show a good performance for these companies. Liquidity as a description of the ability to run the company's operations will create investor confidence in the company, so that investors are interested in investing. Investors' appetite for investment will increase the company's share price, and thus the value of the company will increase.

Several studies on the working capital management have been done before, and some of the researchers assume that the working capital management is very important, because it can affect the performance of the company and the value of the company. Taleb, Zoued, and Shubiri (2010) state that the effectiveness of working capital management is very important, as this will affect the performance and liquidity of the company. The efficiency of working capital management is a fundamental part of the management strategy for creating shareholder value (Nazir \& Afza, 2008).

Deloof (2003) found that managers can create value for shareholders by lowering the day of collection of receivables and minimize the average rate of return for supplies. The results of their study indicate that the receivable collection period is getting shorter and inventories can increase the confident level of investors, so the stock price goes up, and the value of the company or shareholders increased. Azhar and Norita (2010) found that the current assets to total assets ratio show a positive and significant relationship with the firm value (Tobin's Q) and corporate performance (ROA and ROIC). Cash convention cycle and current liabilities to total assets ratio have a negative and significant effect on firm value (Tobin's Q) and corporate performance (ROA and ROIC). Current ratio has a negative effect and significant impact on ROA and ROIC, while the Tobin's Q has a negative but not significant effect.

Narware (2004) found a negative relationship between the profitability and working capital management, where the proportion of the increase in the company's profitability is lower than the proportion of decrease in working capital. Raheman and Nasr (2007) found a strong negative relationship between working capital management (liquidity) and the company’s profitability. While Chowdhury and Amin (2007) found that there is a positive relationship between working capital management and financial performance. Likewise, the results of Mousavi and Jari (2012) show a positive and significant relationship between working capital management (Net Liquidity Balance), corporate performance (ROA), and value (P/BV).

Uchida (2006) found that the company's performance (ROA) has a significant positive effect on firm value (Tobin's Q). Likewise, the results of research from Alghifari, Triharjono, and Juhaeni (2013) found that the company's performance (ROA) has a significant positive effect on firm value (Tobin’s Q). Vural, Sõkmen, and Çetenak (2012) found that working capital management (Cash Conversion Cycle-CCC) has a negative and significant impact on the firm value (Tobin's Q). However, average days in accounts receivable, average days in inventory, average days of accounts payable, and the operating cycle have no relationship with the enterprise value (Tobin's Q).

Nazir (2009) shows that there are some indications how the market performance (Tobin's Q) responds to aggressive working capital. As the opposite happens aggressive working capital has an effect on corporate performance (ROA). The results of this study support the results of Afza and Nazir (2007). Their research was to examine the effect of aggressive working capital on the company's performance, as measured by Tobin's. The result showed that the aggressive working capital was related to stock market performance (Tobin’s Q). 
H1: Working Capital has an effect on firm performance.

H2: Working Capital has an effect on firm value.

\section{Research Design}

\section{Data and Research Variable}

This study uses data after economic crisis of Indonesia in 2008, i.e. 2010-2013. Data were obtained from Indonesian Capital Market Directory (ICMD). The data collection uses purposive sampling methods. The variables used in this study are the capital structure, working capital, the company's performance, and the value of the manufacturing companies, where the capital structure and working capital are an independent variable as proxies by Leverage (LEV), Current Assets to Total Assets (CATA), and Current Liabilities to Total Assets (CLTA). The company's performance is the dependent variable as proxies by Return on Assets (ROA) for the capital structure and working capital, while the value of the company is also a dependent variable for the performance of the company as proxies by Tobin's Q.

Equation 1: Firm Performance $=a_{11}+b_{11}$ Lev $+b_{12}$ CATA $+b_{13}$ CLTA $+e_{11}$

Equation 2: Firm Value $=\mathrm{a}_{21}+\mathrm{b}_{22} \mathrm{ROA}+\mathrm{e}_{21}$

\section{Empirical Research}

Empirical data were analyzed using regression model to estimate the effect of capital structure and working capital on the company's performance, and influence the company's performance on company value. The results of the analysis (equation 1 and equation 2) respectively can be explained as follows.

\section{Equation 1}

Multiple regression equation 1 shows the three independent variables, namely the policy of working capital proxies by CATA and CLTA, as well as the financing or capital structure policy proxies with leverage. The dependent variable is a proxy for the performance of the company Return on Assets (ROA). Regression analysis showed that the leverage and CLTA have a significant negative effect on a significant level of less than one percent. Meanwhile, CATA has a positive and significant impact on a significance level of less than 10 percent.

Based on the results of the statistical test, there are statistically working capital management policies having a significant effect on the performance of the company, so working capital management will have an impact on the company's performance. Although CLTA has a positive effect on the significant level of less than 10 percent, this indicates a positive effect, so if working capital plus, firm performance will increase. This condition is in accordance with the basic concepts of additional working capital, which is to maintain the company's operations so that companies do not lack of working capital.

The existence of sufficient working capital will allow production to be smooth in running the production process, because there is never a delay in raw materials. It is certainly very helpful in the sales department to market its products to meet consumer needs, and product shipments to customers are not constrained by delays in production. Along with the smooth process of production and sales, the generated profit will also increase, and if this condition can be maintained, it is certainly very good for the future development of the company.

Policy of short-term funding sources (CLTA) has a significant negative effect on a significant level of less than one percent, both statistically illustrating the basic concept of the source of funding is appropriate. Increase 
in short-term debt obligations will add capital cost increases, and this may reduce profits. This condition is not the issues of the company for additional profit generated from the short-term debt greater than their cost of capital. This study proved that the use of short-term debt will lower earnings or the company's performance, and increased working capital will increase profits or performance of the company.

Further testing is through the control variables, namely the debt policy (leverage), where the results of statistical analysis showed that leverage has a significant negative effect on a significant level of less than one percent. These results indicate that the use of funds is not optimal, where the capital cost of the use of funds is still greater than the rate of return. This condition can be understood considering that the study was conducted in the period after the 2008 economic crisis, so that some manufacturing companies in BEI were still in a state of recovery, and the global economy's pressure was still very heavy.

The average of Return on Assets (ROA) of the manufacturing company during the period 2010 to 2013 is 7.62 percent with the lowest ROA -1.16 percent and the highest 21.01 percent. Return on Assets (ROA) is almost the same, and only slightly above the benchmark interest rate of Bank Indonesia amounting to 7.50 percent. This shows that there are still many companies that manufacture ROA below the Bank Indonesia benchmark interest rate as global economic pressures are very heavy.

\section{Equation 2}

Equation 2 is only one independent variable, namely the performance of companies as proxies by Return on Assets (ROA), with one dependent variable, i.e. the value of the company as proxies by Tobin's Q. Results of the analysis showed that the corporate performance (ROA) has a significant negative effect on firm value (Tobin's Q) at a significant level of less than one percent. Thus, the increase in corporate performance (ROA) responded negatively to investors. The increase in corporate performance (ROA) is not to be perceived as a positive signal for future investors. This condition could be caused because the Indonesian economy is not yet stable under the global economic pressures, so that more investors are speculating to pursue short-term profits through the spread of stock prices.

\section{Conclusion}

Policy of working capital management in determining the amount of working capital, either through management of current assets or through the determination of short-term funding sources affects the performance of the company. Effect of the working capital management on corporate performance is in conformity both statistically and conceptually. Most of manufacturing companies in Indonesia Stock Exchange have not used its debts effectively and efficiently to decrease the performance of the company. The company's performance is not to be perceived as a positive signal for future investors, causing speculative investors to obtain short-term gains through the spread of share price.

The implications of the results of this study are that the manager must increase the efficiency and effectiveness of working capital management to improve company performance. On the other hand, management should also increase more efficient and effective overall debt (short term and long term), given that the use of this debt will be added to the company's expense. Therefore, management should be able to improve its performance by generating a rate of return on the additional debt higher than their cost of capital with Return on Equity (ROE) increased. Increasing Return on Equity (ROE) will be a positive signal to investors and potential investors to buy its shares. 


\section{References}

Afza, T., \& Nazir, M. S. (2007). Is it better to be aggressive or conservative in managing working capital? Paper Presented at Singapore Economic Review Conference (SERC) (August), 02-04, Singapore.

Azhar, N. E., \& Norita, M. (2010). Working capital management: The effect of market valuation and profitability in Malaysia. International Journal of Business and Management, 5, 140-147.

Alghifari, S. E., Triharjono, S., \& Juhaeni, Y.-Y. S. (2013). Effect of return on assets (ROA) against Tobin's Q: Studies in food and beverage company in Indonesia stock exchange years 2007-2011. International Journal of Science and Research (IJSR), 2.

Brigham, E. F., \& Houston, J. F. (1998). Fundamentals of financial management (8th ed.). Harcourt Inc.

Chowdhury, A., \& Amin, M. M. (2007). Working capital management practiced in pharmaceutical companies listed in Dhaka Stock Exchange. BRAC University Journal, 4, 75-86.

Christopher, S. B., \& Kamalavalli, A. L. (2009). Sensitivity of profitability to working capital management in Indian corporate hospital. Online available: http://ssrsn.com/abstract=1331500

Deloof, M. (2003). Does working capital management affect profitability of Belgian firms? Journal of Business Finance and Accounting, 30, 573-588.

Eljelly, A. (2004). Liquidity-profitability tradeoff: An empirical investigation in an emerging market. International Journal of Commerce and Management, 14(2), 48-61.

Ganesan, V. (2007). An analysis on working capital management efficiency in telecommunication equipment industry. Rivier Academic Journal, 3, 1-10.

Koh, A., Ang, S. K., Brigham, E. F., \& Ehrhardt, M. C. (2014). Financial management: Theory \& practice. Singapore: Cengage Learning Asia Pte Ltd.

Lamberson, M. (1995). Changes in working capital of small firms in relation to changes in economic activity. Mid-American Journal of Business, 10, 45-50.

Mousavi, Z., \& Jari, A. (2012). The relationship between working capital management and firm performance: Evidence from Iran. International Journal of Humanities and Social Science, 2, 141-146.

Naware, P. C. (2004). Working capital and profitability—An empirical analysis. The Management Accountant, 39, $120-127$.

Nazir, M. S., \& Alza, T. (2008). On the factors determining working capital requirements. Proceeding of ASBBS, $15,293-301$.

Nazir, M. S. (2009). Impact of working capital agresiveness on firm profitability. IABR \& TLC Conference Proceedings. San Antonio, Texas, USA.

Raheman, A., \& Nasr, M. (2007). Working capital management and profitability-Case of Pakistani firms. International Review of Business Research Paper, 3, 279-300.

Siddiquee, M., \& Khan, S. M. (2009). Analyzing working capital performance: Evidence from Dhaka Stock Exchange (DSE) ltd. Online available: http://ssrsn.com

Sudiyatno, B., Puspitasari, E., \& Kartika, A. (2012). The company’s policy, firm performance, and firm value: An empirical research on Indonesia Stock Exchange. American International Journal of Contemporary Research, 2, 30-40.

Taleb, G. A., Zoued, A. N., \& Shubiri, F. N. (2010). The determinant of effective working capital management policy: A case study on Jordan. Interdisciplinary Journal of Contemporary Research in Business, 2, 248-264.

Uchida, K. (2006). Agency costs of debt and the relationship between firm performance and managerial ownership: Evidence from Japan. Faculty of Economics and Business Administration, 802-8577.

Vural, G., Sõkmen, A. G., \& Çetenak, E. H. (2012). Affects of working capital management on firm’s performance: Evidence from Turkey. International Journal of Economics and Financial Issues, 2, 488-495. 